Uşak Üniversitesi Sosyal Bilimler Dergisi

$2015,8 / 4$

\title{
Dizi Filmler ve Bilgisayar Oyunlarının Ortaöğretim Öğrencilerinin Şiddet Algisina Etkisi Nitel Bir Araştırma*
}

\author{
Sinan YÖRÜK** \\ Mehmet KOÇYİĞIT \\ Murat TURAN ${ }^{* * *+}$
}

\begin{abstract}
Öz
Araştırmanın amacı dizi film ve bilgisayar oyunlarının ortaöğretim öğrencilerinin zihinlerinde nasıl imgeler bıraktı̆̆ını görebilmek ve buradan yola çıkarak şiddet algıları üzerinde nasıl bir etki yapabileceği hakkında tespitlerde bulunmaktır. Araştırma sosyal olguları bağlı bulundukları çevre içerisinde araştırmayı ve anlamayı esas alan nitel, betimleyici bir araştırma olarak tasarlanmıştır. Araştırmada amaçlı örnekleme tekniklerinden kritik durum örneklemesi kullanılmıştır. İlk olarak, Afyonkarahisar İl Emniyet Müdürlüğü'nün de yardımı ile öğrenciler arasında şiddet olaylarının en fazla yaşandığ 1 okul tespit edilmiş ve daha sonra bu okul örnekleme alınmıştır. Araştırmanın örneklemini 2013 yılında Afyonkarahisar'da bir ortaöğretim kurumunun 9, 10 ve 11 . sinıf öğrencilerinden 42 'si 9. sinıf, 30'u 10. sinıf ve $19^{\prime} \mathrm{u} 11$. sinıf öğrencisi olmak üzere toplam 91 öğrenci oluşturmaktadır. Araştırmada veri toplama yöntemi olarak saha taraması yöntemi kullanılmıştır. Veri toplamak amacıyla öğrencilerden sevdikleri dizi film ve bilgisayar oyunların belirtmeleri ve bunlar hakkında resimler çizmeleri istenmiştir. Dizi film ve bilgisayar oyunları şiddet içeren ve içermeyenler olarak gruplanmış ve bu çerçevede ortaöğretim öğrencilerinin dizi filmler ve bilgisayar oyunları ile ilgili çizimleri betimsel analiz yöntemi de kullanılarak analize tabi tutulmuştur. Şiddet içeren resimlerde rahatça taşınabilecek bıçak vb. gibi kesici aletler ve tabancalar çokça çizilmiş, ölü ve yaralı insanlar resmedilmiştir. Bunun yanında çizilen resimlerde bolca
\end{abstract}

* Bu çalışma, ilk hali 5-7 Eylül 2013 tarihlerinde düzenlenen 22. Ulusal (Uluslararası Katılımlı) Eğitim Bilimleri Kurultayı, Eskişehir'de sunulan sözlü bildirinin geliştirilmiş halidir.

** Doç. Dr., Afyon Kocatepe Üniversitesi Eğitim Fakültesi, Eğitim Bilimleri, Eğit. Yön. Tef. Plan. Ekon. syoruk@aku.edu.tr

*** Afyon Kocatepe Üniversitesi Yab. Dil. Y.O. mkocyigit@aku.edu.tr

***** Afyon Kocatepe Üniversitesi Sosyal Bilgiler Öğretmenliği Yüksek Lisans murat.turan.8181@hotmail.com 
kurşun, kan ve sigara içen karakter çizildiği görülmüştür. Sigara ve tespih gibi objeler şiddet içermeyen resimlerde görülmemektedir.

Anahtar Kelimeler: Ortaöğretim Öğrencileri, Şiddet Algısı, Dizi Filmler, Bilgisayar Oyunları, Okul İçi Şiddet.

\title{
The Effect of TV Series and Computer Games on the Perceptions of Violence of Secondary School Students A Qualitative Study
}

\begin{abstract}
The aim of this study is to define the effects of TV series and computer games on the images in the minds of secondary school students and in this context on their perceptions of violence. The research is designed as a qualitative and descriptive study, which is based on to study and to comprehend the social phenomena in their own contexts. Of the purposeful sampling techniques, critical case sampling technique was used in the study. Firstly, with the help of Afyonkarahisar provincial police headquarters, the school which experiences cases of violence the most was identified and taken into the sampling. The sample consists of a total of 91 secondary school students in Afyonkarahisar, Turkey, in 2013, 42 of which are 9th grade, 30 are 10th grade and 19 are 11th grade. Survey method was used to collect data. In order to collect data, students were asked to indicate the TV series and computer games they like and to draw pictures about these. The pictures about the TV series and the computer games were grouped as violence containing and non-violence containing pictures. These pictures were analysed in this framework using descriptive analysis. It was found out that in the pictures containing violence, sharp objects easy to carry, like knives etc., and pistols and dead and injured people were drawn. In addition there were lots of bullets, blood and smoking people in these pictures. In the pictures that don't contain violence, objects like cigarettes and rosaries cannot be seen.
\end{abstract}

Keywords: Secondary School Students, Perception of Violence, TV Series, Computer Games, School Violence.

\section{Şiddet}

Şiddet; dünya sağlık örgütü tarafından (Krug, Dahlberg, Mercy, Anthony \& Zwi, 2002) kişinin, yaralanma, ölüm, psikolojik zarar veya kayıp ile sonuçlanan veya bunlarla sonuçlanması muhtemel olan fiziksel şiddet ve gücü, tehdit veya fiili olarak, kendisine, başka bir kişiye, bir gruba veya 
topluluğa karşı kasıtlı kullanımı şeklinde tanımlanmıştır. Alanyazın incelendiğinde şiddetin duygusal, fiziksel, sözel, başkalarına yönelik, kişinin kendine yönelik, dolaylı, doğrudan, kolektif, özel, cinsel vb. şeklinde değişik tür ve sınıflamalarının olduğu görülebilmektedir (Alpanık, 2011; Çubukçu ve Dönmez, 2012; Kapıcıŏlu, 2008; Krug ve diğ., 2002; Yörük ve Çankaya, 2013).

\section{Okul İçi Şiddet}

Okul içi şiddet kavramı okul ortamında güçlü durumdaki bir kişinin kendi isteğiyle fiziksel, sözel ya da psikolojik olarak rahatsızlık verici davranışlarda bulunması (Pehlivan, 2008) şeklinde tanımlanabilir. Okulda şiddet dünyada olduğu gibi Türkiye'de de artış göstermektedir (Çubukçu ve Dönmez, 2012). Bu konu ile ilgili olarak Milli Eğitim Bakanlığı [MEB] bazı çalışmalar yaptırmış ve raporlar hazırlatmıştır (bkz. MEB 2008a, 2008b; Erol, 2009).

Okullarda yaşanan şiddet olayları sadece fiziksel zararlara sebep olmamaktadır. Bunun yanında okullarda şiddet "öğrencinin akademik başarısında düşüşe, okul ikliminde bozulmaya, okul bırakmalara sebep olmaktadır ve psikolojik bozukluklar ortaya çıkarmaktadır" (Akbaba Altun ve Erdur Baker, 2010: 3165). Okulda yaşanan şiddet olayları içerisinden özellikle uç şiddet olayları çoğunlukla halkın ve medyanın dikkatini çekiyor olsa da okullarda daha yaygın günlük şiddet olayları (öğrencilerin sosyal gruplardan dışlanması, sözlü ve fiziksel taciz vb. gibi) da mevcuttur. Öğrencilerin okulda her gün karşılaştıkları bu küçük ölçekli şiddetin boyutları ve sonuçları ile ilgili nitel olarak çok az şey bilinmektedir ve bu olaylar kamuoyunda daha az dikkat çekmektedir. Okulda şiddet eğitim sürecinde öğrenci performansı ile ilgili araştırmalarda göz ardı edilen önemli bir faktör olabilir (Ammermueller, 2012). Beycioğlu, Kesik ve Kondakçı'ya göre (2014: 414) “okullarda şiddet sinyali veren çocuklar okullarda sosyal etkinliklere katılmayıp dışarıda kalanlar, evde, okulda ya da çevrede şiddete uğrayanlar, öfkesini kontrol edemeyenler, yoğun disiplin problemi olanlar, geçmişlerinde şiddet ve saldırganca davranışlara maruz kalanlar, farklılıklar konusunda önyargılı olanlar ve içlerindeki şiddeti yazı, resimle dışa vuranlar olarak nitelendirilebilir".

\section{Şiddetin Kaynaklarn ve Medya}

Şiddetin kaynaklarına ilişkin etmenler (tıbbi, psikolojik, bireysel, sosyal, çevresel, kültürel, madde bağımlılığı, aile, okula ilişkin vb. gibi) birçok çalışmada farklı boyutlarıyla ele alınmıştır (Avcı, 2010; Kıran, 2011; Kızmaz, 2006a; Kızmaz, 2006b; MEB, 2008a; Sağlam, 2011; Şener ve Boydak 
Özan, 2013; Tezcan, 2009). Bu etmenlerle birlikte bilgisayar, internet ve televizyon göz ardı edilemeyecek bir yer tutmaktadır ve çocuklarda ve gençlerde bir takım davranış bozukluklarının ve şiddet eğiliminin artmasının internet, bilgisayar ve televizyon (ve hatta cep telefonu vb.) gibi medya ve kitle iletişim araçlarındaki olumsuz yayınlarla ilişkisini tespit etmek amacıyla yapılan çalışmalar çoğalmaktadır (Browne ve HamiltonGiachritsis, 2005; Cantor, 2000; Carnagey, Anderson ve Bushman, 2007; Demirok ve diğ., 2012; Dill ve Dill, 1998; Funk ve diğ., 2004; Gentile ve diğ., 2004; Griffiths, 2009; Huesmann, 2007).

Bilgisayar oyunları ve televizyon gibi medya araçlarının şiddetle ilişkisi hakkında yapılan çalışmalar incelendiğinde bu çalışmaların genel olarak ikiye ayrıldığı söylenebilir. Çalışmaların bir kısmı bilgisayar oyunları ya da diğer medya araçlarının şiddetle kanıtlanmış bir ilişkisi olmadığını ya da en azından tek kaynak olarak gösterilemeyeceğini, farklı kişisel ya da ailesel faktörlerin daha önemli değişkenler olabileceğini (Ferguson ve dĭ̆., 2008; Ferguson, 2011) veya 'bilgisayar oyunlarındaki şiddetin gençlerde var olan şiddet eğilimlerini boşalttığı dolayısıyla faydalı olabileceğini' (Sağlam, 2011 :2) savunabilmektedir. Diğer grup çalışmalar ise bilgisayar oyunları ve televizyon gibi diğer medya araçlarının şiddet, şiddet içeren davranışlar, duygusuzlaşma, saldırganlık, sinirlilik, geleceğe yönelik beklentilerin düşük olması gibi kavramlarla ilişkisi olduğunu belirtmektedir (Carnagey, Anderson ve Bushman, 2007; Demirok ve diğ., 2012; Funk ve diğ., 2004; Gentile ve diğ., 2004; Griffiths, 2009; Kıran, 2011; Sağlam, 2011).

"Burada önemli olan faktörler; bilgisayar oyununun özelliğinden, ne kadar oynadığına; çocuğun sosyal çevresinden, kendini ne ile özdeşleştirdiğine kadar değişmektedir" (Sağlam, 2011: 2). Kıran, (2011: 25) bilgisayar oyunları ve özelde şiddet içeren bilgisayar oyunlarının çocuklar ve gençler üzerindeki muhtemel zararlı etkilerini şu şekilde açıklamaktadır: "Bilgisayar oyunlarına bağlandıkça bireyler zamanla gerçek hayatı ve sanal ortamı birbirine karıştırmaktadırlar. Özellikle çocuk ve gençler bu oyunlardan çok daha fazla etkilendikleri için oyun karakterlerinin davranışlarını kendilerine model alarak gerçek hayata yansıtabilmektedirler. Oyun ortamlarındaki şiddetin ağrısız, acısız olması bunu günlük hayatta uygulama düşüncesini kolaylaştırmaktadır".

Şiddet unsurları içeren televizyon dizilerinin de içine dâhil olduğu kitle iletişim araçları yayınları saldırganlık gösteren rol modellerle karşılaşmaya sebep olmaları açısından önemlidir. Bireyler medyada gördükleri şiddet olayları ile insanlara zarar vermenin ve şiddetin yeni şekillerini öğrenerek davranışlarına katmaktadır. Saldırganlık gösteren örneklerle karşılaşma sonucu (filmlerdeki, televizyondaki şiddet, vb.) 
bireylerin şiddete maruz kalmasalar bile, model alma yoluyla, sorun çözme yolu olarak şiddeti öğrenme aracılığıyla ve bu tür davranışların sonuçlarına karşı duyarsızlaşma yoluyla saldırganlığa eğilimli hale geldiği görülmektedir (Kapıcıoğlu, 2008).

\section{Araştırmanın Önemi}

Araştırmanın önemini ortaya koymak adına Türkiye İstatistik Kurumu'nun yayınladığı bazı istatistikler yardımcı olabilecektir. Bunlara göre bilgisayar kullanımına ortalama 8 yaşında başlanmaktadır. İnternet kullanımına ortalama başlama yaşı 9, internet kullanım yerlerine göre de $\% 65,6$ ile ev ilk sırada gelmektedir. Yine bu istatistiklere göre çocukların $\% 60,5^{\prime}$ i bilgisayar, \%50,8'i İnternet, \%24,3'ü cep telefonu kullanmıştır ve $\% 45,6$ 's ' hemen her gün internet kullanmıştır.

06-15 yaş grubu çocuklar İnterneti en çok \%84,8 ile ödev veya öğrenme amaciyla kullanırken, bunu \%79,5 ile oyun oynama, \%56,7 ile bilgi arama, \%53,5 ile sosyal medya ağlarına katılma takip etmektedir. Her on çocuktan dokuzu hemen her gün TV izlemiştir. 11-15 yaş grubu çocuklar tarafından en çok izlenen program türü ise $\% 76,8$ ile film ve dizilerdir (TÜIK, 2013a). Bilgisayar ve İnternet kullanım oranlarının en yüksek olduğu yaş grubu 16-24'tür. Bilgisayar ve İnternet kullanımı tüm yaş gruplarında erkeklerde daha yüksektir. Bireylerin $\% 39,5$ 'i düzenli olarak internet kullanmaktadır (TÜİK, 2013b). Bu veriler internet, bilgisayar ve televizyonun insanların hayatında ne kadar yer tuttuğunu göstermektedir.

Yukarıda verilen istatistiki bilgiler çocukların ve ergenlik dönemindeki gençlerin televizyon, internet ve bilgisayar oyunları ile ne kadar içli dışı olduklarını da ortaya koymaktadır. Özellikle 12-18 yaş arası dönem, bir başka deyişle ortaokul ve lise yıllarını kapsayan dönem bireyin sosyo-duygusal gelişimi ve kimlik kazanımı açısından çok önemli bir dönemdir (Slavin, 2013; Yeşilyaprak, 2013). Bu dönemde gençlere olumlu rol modeller araştırmaları için fırsatlar sunulmalıdır (Yeşilyaprak, 2013). Çünkü benlik kavramı, sosyal ilişkiler, duygusal gelişim gibi kritik aşamaları barındıran bu dönemde ergenler uzun vadede olumsuz sonuçlar oluşturabilecek duygusal bozukluklar, zorbalık, okulu bırakma, madde kullanımı, çeşitli suçlar gibi davranışlar gösterebilirler (Slavin, 2013). Dolayısıyla bu araştırmada şiddet olaylarının en çok kayda geçtiği bir liseden örneklem alınmış olması bu anlamda önemlidir.

Bununla birlikte, okulun güvenliğinin sağlanması okul müdürünün sorumlulukları arasında olsa da (Şişman, 2011), okullarda şiddet olayları görülmeye devam etmekte ve şiddetin önlenmesi veya azaltılması konusunda sadece okul yönetimi, öğretmen ya da güvenlik güçleri yeterli 
olamamaktadır. Bu açıdan şiddetin kaynaklarına inilmesi ve bunların ışığında çözümler aranması önemlidir. Konunun öneminin yanında, araştırmanın öğrencilere resim çizdirme yoluyla veri toplayan nitel bir araştırma olması, öğrencilerin zihinlerindeki imgeleri doğrudan ve derinlemesine görebilmek ve analiz edebilmek adına diğer araştırmalardan farklılık göstermektedir.

\section{Araştırmanın Amacı}

Araştırmanın amacı dizi film ve bilgisayar oyunlarının ortaöğretim öğrencilerinin zihinlerinde nasıl imgeler bıraktığını görebilmek ve buradan yola çıkarak şiddet algıları üzerinde nasıl bir etki yapabileceği hakkında tespitlerde bulunmaktır.

\section{Yöntem}

Araştırma sosyal olguları bağlı bulundukları çevre içerisinde araştırmayı ve anlamayı esas alan nitel, betimleyici bir araştırma olarak tasarlanmıştır. "Betimsel araştırmalar, olayı olduğu gibi araştırmaya ve var olan durumu belirlemeye çalışan araştırmalardır" (Tanrı̈ğgen, 2009: 59). Araştırmada veri toplama yöntemi olarak saha taraması yöntemi kullanılmıştır. Tarama (survey) betimsel araştırmalarda kullanılan yaygın yöntemlerin başında gelmektedir (Tanrıöğen, 2009).

Veri toplamak amacıyla öğrencilerden sevdikleri dizi film ve bilgisayar oyunlarını belirtmeleri ve bunlar hakkında resimler çizmeleri istenmiştir. Dizi film ve bilgisayar oyunları şiddet içeren ve içermeyenler olarak gruplanmış ve bu çerçevede ortaöğretim öğrencilerinin dizi filmler ve bilgisayar oyunları ile ilgili çizimleri betimsel analiz yöntemi de kullanılarak analize tabi tutulmuştur. Betimsel analizde veriler önceden belirlenen temalara göre özetlenir ve yorumlanır (Yıldırım ve Şimşek, 2008). Bu araştırmada delici ve kesici aletler, küfürlü ya da argo sözler, kan, ölü, yaralı, mermi, bomba vb. gibi şiddetle ilgili olabilecek tüm materyalleri içeren resimler 'şiddet unsuru içeren resimler' olarak gruplanmıştır. Bunların dışında araba, sarılan insanlar, halay çekenler vb. gibi öğeleri de barındıran fakat yukarıda sıralanan şiddetle ilgili materyalleri içermeyen resimler 'şiddet unsuru içermeyen' resimler olarak gruplanmıştır. Araştırmacılar ilk olarak çizilen resimleri yukarıda belirtilen kriterlere göre şiddet içeren ve içermeyen olarak ayırmışlar, daha sonra ikinci bir değerlendirme ile resimler üzerinde daha ayrıntılı bir analiz yapmışlardır. Bu analizde dizi ve oyunların isimleri ve resimlerde çizilen objeler belirlenmiştir ve resimlerin hangi gruba dâhil edilmesi gerektiği tekrar değerlendirilmiş ve karar buna 
göre verilmiştir. Veriler bu çerçeve altında bulgular kısmında özetlenmiş, sonuç ve tartışma bölümlerinde yorumlanmıştır.

Nitel araştırmada "geçerlik" bilimsel bulguların doğruluğu, "güvenirlik" ise bilimsel bulguların tekrarlanabilirliği ya da başka bir ifade ile farklı araştırmacılar açısından da araştırmacının yaklaşımının tutarlılığı ya da kararlılığı ile ilgilidir (Creswell, 2013; Yıldırım ve Şimşek, 2008). Bu doğrultuda araştırmanın geçerliğini artırmak için araştırma süreci olabildiğince ayrıntılı bir şekilde açıklanmaya çalışılmıştır. Araştırmanın güvenirliğini artırmak için bulgular öncelikle yorum yapılmadan doğrudan verilmiştir ve öğrencilerin çizdikleri resimlerden örnekler raporda sunulmuştur.

\section{Örneklem}

Araştırmada amaçlı örnekleme tekniklerinden kritik durum örneklemesi kullanılmıştır. "Kritik bir durum veya durumların varlığına işaret eden en önemli gösterge 'bu, burada oluyorsa, başka benzer durumlarda kesinlikle olur' ya da tam tersine 'bu, burada olmuyorsa, başka benzer durumlarda kesinlikle olmaz' şeklinde bir ifadedir" (Yıldırım ve Şimşek, 2008: 110). Eğer şiddet oranının yüksek olduğu bu örneklemde şiddet içeren dizi ya da bilgisayar oyunları ile ilgili resimler az sayıda çıkar ya da hiç çıkmazsa bu diğer okullar için de benzer bir eğilim gösterecektir.

İlk olarak, Afyonkarahisar İl Emniyet Müdürlüğü'nün de yardımı ile öğrenciler arasında şiddet olaylarının en fazla yaşandığ 1 okul tespit edilmiş ve daha sonra bu okul örnekleme alınmıştır. Okulda rehberlik öğretmeni ile işbirliği içerisinde bu açıdan en sorunlu olduğu düşünülen şubeler belirlenmiş ve örneklem bu şekilde oluşturulmuştur. Araştırmanın örneklemini Afyonkarahisar'da bir ortaöğretim kurumunun 9, 10 ve 11. sinıf öğrencilerinden $42^{\prime}$ si 9. sınıf, 30'u 10. sınıf ve 19'u 11. sınıf öğrencisi olmak üzere toplam 91 öğrenci oluşturmaktadır. Okulun isminin kimseyi ifşa etmemek ya da zan altında bırakmamak adına gizli tutulması gereği düşünülmüştür.

\section{Sinırlılıklar}

- Çalışmanın örnekleminin alındığı eğitim kurumunun okul türünden dolayı örneklemdeki kız öğrenci sayısı oldukça düşüktür.

- Çalışma örneklemi 2012-2013 öğretim yılında örneklemin alındığı eğitim kurumunda 9, 10 ve 11. sinıflarda okuyan öğrenciler ile sınırlıdır. 


\section{Bulgular}

Daha önce de belirtildiği gibi yapılan resimlerin analizi esnasında delici ve kesici aletler, küfürlü ya da argo sözler, kan, ölü, yaralı, mermi, bomba vb. gibi şiddetle ilgili olabilecek tüm materyalleri içeren resimler 'şiddet unsuru içeren resimler' olarak gruplanmıştır. Bunların dışında araba, sarılan insanlar, halay çekenler vb. gibi öğeleri de barındıran fakat yukarıda sıralanan şiddetle ilgili materyalleri içermeyen resimler 'şiddet unsuru içermeyen' resimler olarak gruplanmıştır. Bulgular rapor edilirken öğrencilerin bulundukları sınıf seviyesi de dikkate alınmış ve bulgular 9, 10 ve 11. sinıflar için gruplanarak rapor edilmiştir. Bu şekilde okuyucunun farklı sınıf seviyelerinde olan öğrencilerin ilgilerinin hangi oyun ve dizilere toplandığını ve zihinlerinde nasıl imgeler bıraktıklarını görebilmesi hedeflenmiştir.

\section{Sınıflarda Yaptırılan Resim Çalışmasının İ̧̧eriği}

40 Erkek, $2 \mathrm{~K}$ zz toplam: 42 öğrencinin oluşturduğu bu grupta, 22 şiddet unsuru içeren resim; 20 şiddet unsuru içermeyen resim bulunmaktadır. Yapılan resimlere bakıldığında; dizilerle ilgili çizilen resimlerde silahların kullanıldığı, yerde yaralı veya ölü halde insanların çizildiği, birçok keski aletinin kullanıldığının çizildiği, tankın üzerine çıkmış bir insanın çizildiği bir resimde "Allah cezanı versin" diyen bir adamın çizildiği görülmüştür. Bilgisayar oyunlarıyla ilgili çizilen resimlerde ateş eden, karşı tarafı yok etmeye çalışan alet ve makinaların çizildiği, silah ve bıçakların, ateş eden ya da bıçak çeken insanların çizildiği, yerde yatan ölü veya yaralı insanların çizildiği görülmüştür.

Şiddet unsuru içeren bu 22 resmin 2 tanesi Counter adlı bilgisayar oyununa, 3 tanesi Darkorbit adlı bilgisayar oyununa, 1 tanesi Gta adlı bilgisayar oyununa 1 tanesi Wolfteam adlı bilgisayar oyununa, bir tanesi de Yenilmez 3 adlı bilgisayar oyununa aittir. Geri kalan şiddet unsuru içeren 14 resmin ise 5 tanesi Kurtlar Vadisi Pusu dizisine, 3 tanesi Arka Sokaklar dizisine, 1 tanesi İki Dünya Arası dizisine, 1 tanesi Şahin ve Çetesi dizisine, 1 tanesi Avrupa Avrupa dizisine (sözel şiddet, hakaret), 1 tanesi Benim İçin Üzülme dizisine, 1 tanesi Nizama Adanmış Ruhlar dizisine, 1 tanesi Ustura Kemal dizisine aittir. Şiddet unsuru içermeyen 20 resim ise bilgisayar oyunları olarak araba yarışına (NFS), 3 tanesi futbol oyununa (PES 13, fifa 2007), 1 tanesinin Titanik adlı oyuna, 1 tanesinin Bilardo oyununa, 1 tanesinin Tenis oyununa ait olduğu görülmüştür. Resmi çizilen ve şiddet unsuru içermeyen dizilerden ise 1 tanesinin Aşk-1 Memnu'ya (iki kişinin birleşmesi), 1 tanesinin Akasya Durağı adlı diziye, 1 tanesinin Seksenler adlı diziye, 1 
tanesinin Alemin Kralı adlı diziye, 1 tanesinin de Pis Yedili adlı diziye ait olduğu görülmüştür.

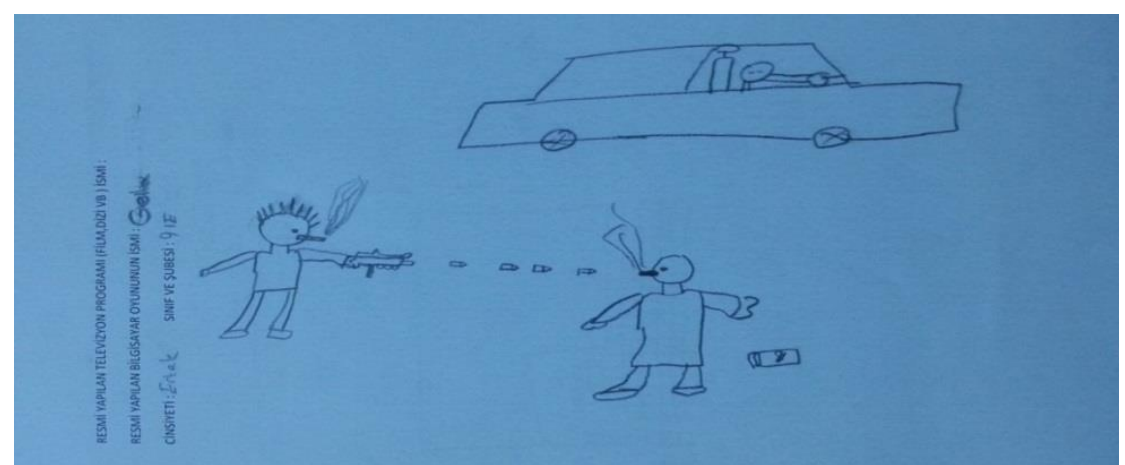

Resim 1. 9. Sınıflarda Yaptırılan Resim Çalışmasından Şiddet İçeren Bir Resim Örneği

\section{Sınıflarda Yaptırılan Resim Çalışmasının İçeriği}

10. sınıflardan 28 erkek, 2 kız toplam 30 öğrenci ile resim çalışması yapılmıştır. Bu resim çalışmalarında 10 tane şiddet unsuru içeren resim, 20 tane şiddet unsuru içermeyen resim bulunmaktadır. Dizilerle ilgili çizilen resimlerde silahla ateş eden insanların olduğu, yerde yatan ölü veya yaralı insanların olduğu, oynanan bilgisayar oyunları ile ilgili çizilen resimlerde ise silahla ateş eden, ellerinde kesici aletler bulunan insanların olduğu görülmüş̧ür.

Şiddet unsuru içeren 10 resmin 3 tanesi Kurtlar Vadisi Pusu adlı diziye, 2 tanesi Ekip 1 adlı bilgisayar oyununa, 2 tanesi Wolf Team adlı bilgisayar oyununa, 2 tanesi Elm Sokağında Kabus adlı bilgisayar oyununa, 1 tanesi de Metin 2 adlı bilgisayar oyununa aittir. Şiddet unsuru içermeyen 20 resmin 3 tanesinin Aşk-ı Memnu adlı diziye, 3 tanesinin Pis Yedili adlı diziye, 2 tanesinin Leyla ile Mecnun adlı diziye, 1 tanesinin Yalan dünya adlı diziye ait olduğu görülmüştür. Bilgisayar oyunu ile ilgili resimlerin 7 tanesinin futbolla ilgili (fifa, PES), 2 tanesinin Euro Truck Simulator adlı bilgisayar oyununa, 1 tanesinin voleybolla ilgili bilgisayar oyununa ve 1 tanesinin de Yüzüklerin Efendisi adlı bilgisayar oyununa ait oldukları görülmüştür. 


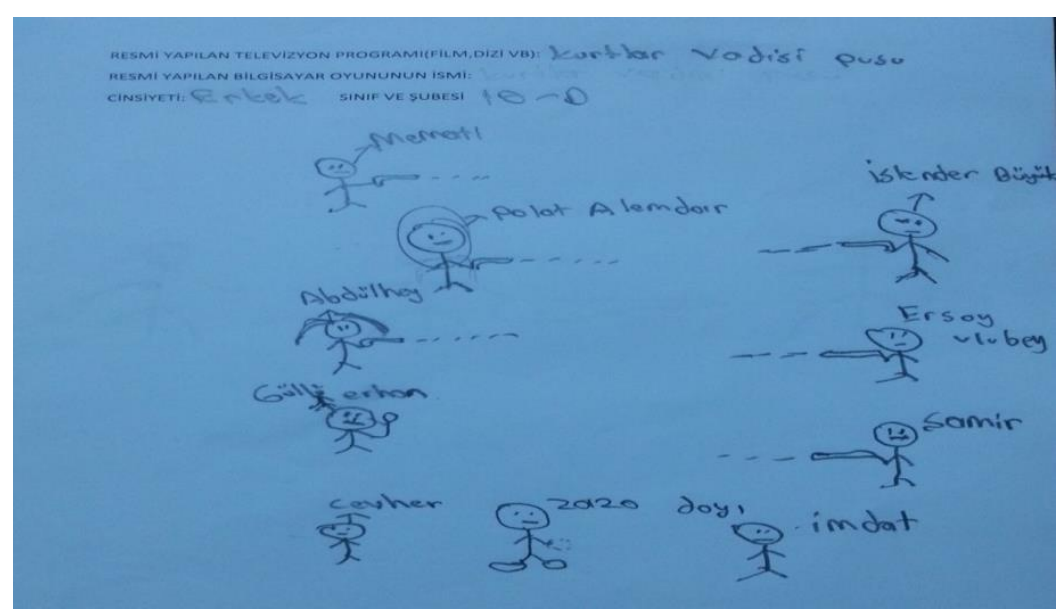

Resim 2. 10. Sınıflarda Yaptırılan Resim Çalışmasından Şiddet İçeren Bir Resim Örneği

\section{Sınıflarda Yaptırılan Resim Çalışmasının İçeriği}

11. sınıflarda 19 erkek öğrenci ile resim çalışması yapılmıştır. 13 tane şiddet unsuru içeren, 6 tane şiddet unsuru içermeyen resim yapılmıştır. Yapılan resimler incelendiğinde silahla ve roketle ateş eden insanların çizildiği, ayrıca kılıç benzeri kesici bir alet çizildiği görülmüştür.

Şiddet unsuru içeren 13 tane resmin 3 tanesi Kurtlar vadisi adlı diziye, 2 tanesi Sakarya Fırat adlı diziye, 2 tanesi Şefkat Tepe isimli diziye, 2 tanesi Arka Sokaklar isimli diziye ait olup, 1 tanesi Counter adlı bilgisayar oyununa 2 tanesi de Metin 2 adlı bilgisayar oyununa aittir. Şiddet unsuru içermeyen 6 resmin ise 3 tanesinin Pis Yedili adlı diziye, 1 tanesinin Bil ve Fethet bilgisayar oyununa, 1 tanesinin Euro Truck Simulator adlı bilgisayar oyununa ait olduğu görülmüştür. Bir resmin ise hangi dizi veya bilgisayar oyununa ait olduğu anlaşılamamıştır. 


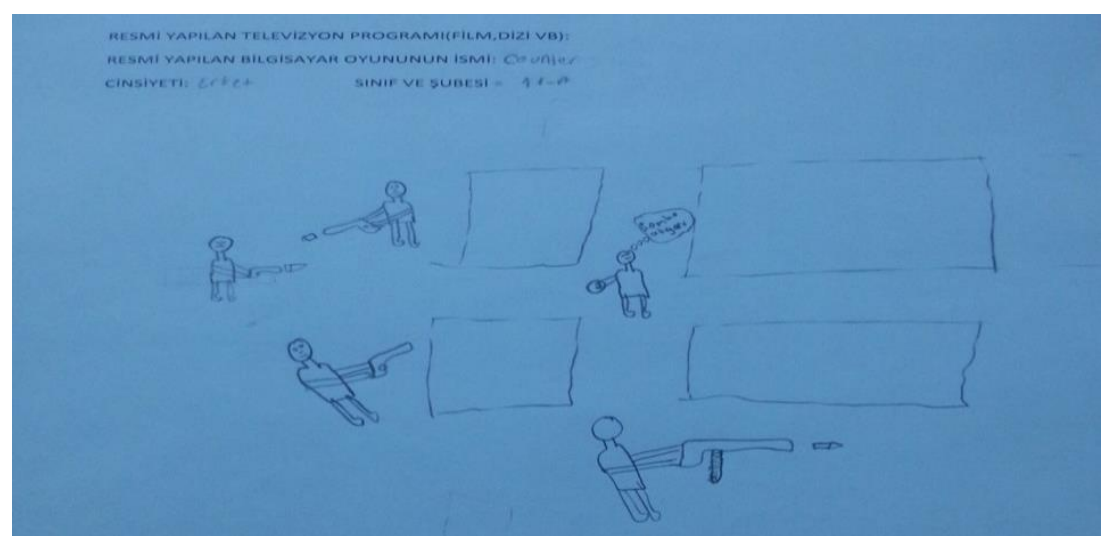

Resim 3. 11. Sınıflarda Yaptırılan Resim Çalışmasından Şiddet İçeren Bir Resim Örneği

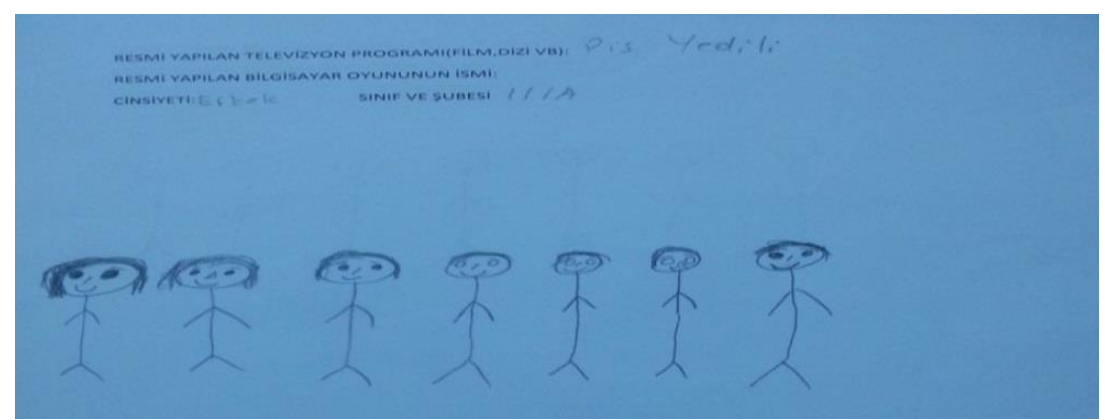

Resim 4. Şiddet Unsuru İçermeyen Resimlere Bir Örnek

\section{Sonuçlar}

Toplam 91 öğrencinin çizdikleri resimlerden 45 tanesi şiddet unsurları içerirken 46 tanesi şiddet unsurları içermemektedir. Bu oldukça yüksek bir orandır. Çizilen resimlerde rahatça taşınabilecek bıçak vs. gibi kesici aletlerin ve tabancaların çokça bulunması, ölü ve yaralı insanların resmedilmiş olması bilgisayar oyunları ve televizyon dizilerinin öğrencilerin akıllarında nasıl imgeler bıraktığını ortaya koymaktadır. Silah ve kesici aletlerin yanında çizilen resimlerde bolca kurşun, kan ve sigara içen karakter de dikkatlerden kaçmamaktadır. Sigara ve tespih gibi objeler şiddet içeren resimlerde çokça görülürken şiddet içermeyen resimlerde görülmemektedir.

\section{Tartışma}

Konu ile ilgili yapılan bazı araştırmalar bilgisayar oyunları ya da televizyon gibi kitle iletişim araçlarındaki yayınların şiddetle kanıtlanmış 
kuvvetli bir ilişkisi olmadığını ya da en azından tek kaynak olarak gösterilemeyeceğini, farklı kişisel ya da ailesel faktörlerin daha önemli değişkenler olabileceğini (Ferguson ve diğ., 2008; Ferguson, 2011) belirtse de konu ile ilgili yapılan çalışmaların çoğunda şiddet ya da şiddeti doğuran unsurlarla ve bu unsurların bazı olumsuz sonuçlarıyla söz konusu yayınların ilintili olabileceği belirtilmiştir (Carnagey, Anderson ve Bushman, 2007; Demirok ve diğ., 2012; Funk ve diğ., 2004; Gentile ve diğ., 2004; Griffiths, 2009; Kıran, 2011; Sağlam, 2011). Bu çalışmada elde edilen nitel bulgular da bu tespite aykırı bir durum ortaya koymamaktadır. Aksine oynadıkları bilgisayar oyunları ya da izledikleri dizilerin öğrencilerin zihin dünyasında sözel ya da fiziksel şiddeti çağrıştıran çok farklı imgeler bırakabildiği gözlemlenmiştir. Veriler resim çizdirme yolu ile toplandığı için de bu imgelerin öğrencinin zihninden doğrudan kâğıda aktardığı şekilde görülebilmesi mümkün olmuştur.

Bireylerde şiddet algısının şekillenmesinde, ya da zihinlerindeki şiddete dair imgelerin oluşmasında tek etken olarak diziler ve bilgisayar oyunları gösterilemese de, öğrencilerin gerçek hayatlarında araştırma için resmettikleri birçok nesneyi gör(e)meyecekleri ya da kullan(a)mayacakları unutulmamalıdır. Yani bir lise öğrencisinin sokakta yürürken 1şın kılıcı ya da roketatarla birbirini öldürmeye çalışan insanlar görmesi normal şartlar altında pek mümkün değildir. Bu durumda hiç görmeyip kullanmadıkları nesneler ya da olaylar hakkında zihinlerinde ya da bilinçaltlarında bunlara benzer şiddet imgeleri çoğunda belki hiç oluşmayacaktı. Ama sevdikleri diziler ve oyunlar sayesinde yüzde elliye yakın bir oranda zihinlerinde şiddet içeren imgelere sahip oldular ve şiddet algıları bu şekilde etkilenmiş oldu. Kapıcıŏ̆lu'nun da belirttiği gibi şiddete maruz kalmamış olsalar da şiddetin farklı şekillerini öğrenmiş oldular (2008). Şiddet olaylarının en çok yaşandığı bir okulda bu şekilde bir sonuç çıkmış olması da manidardır.

Daha önce, araştırma örnekleminin de dâhil olduğu 12-18 yaş arası dönemin bireyin sosyo-duygusal gelişimi ve kimlik kazanımı açısından çok önemli bir dönem olduğu (Slavin, 2013; Yeşilyaprak, 2013) ve bu dönemde gençlere olumlu rol modeller araştırmaları için fırsatlar sunulması gerektiği (Yeşilyaprak, 2013) belirtilmişti. Bunlarla beraber çocuk ve gençlerin oyun karakterlerini model alıp şiddet davranışını gerçek hayatta uygulayabileceği (Kıran, 2011) ya da bu tür örnekleri film ya oyunlarda görüp şiddete karşı duyarsızlaşabileceği de (Kapıcıŏ̆lu 2008) hatırlanırsa, öğrencilerin zihinlerinde şiddetle ilgili bu şekilde imgeler bırakan oyun ve dizi filmlerin bu anlamda da olumsuz etkilere sahip olabileceği tartışılabilir.

Okullardaki şiddet olaylarını incelerken bilgisayar oyunları ve televizyon dizileri gibi medya değişkenlerini de dikkate almak 
gerekmektedir. Burada aynı zamanda okullarda şiddetin önlenmesi veya azaltılması konusunda sadece okul yönetimi ya da öğretmen ya da güvenlik güçlerine sorumluluğuna bırakılması objektif bir yaklaşım olmayacaktır. Ailelerden televizyon kanallarına, bilgisayar oyunu üretenlerden internet servis sağlayıcılarına kadar çok geniş bir yelpazede okullarda şiddet olgusunun ele alınması gerekmektedir.

\section{Öneriler}

- Ailelerin televizyon izleme alışkanlıklarını gözden geçirmesi ve çocukları ile beraber izledikleri programlarda seçici olmaları gerekmektedir.

- Eğitici içerikli, ders amaçlı video ve grafiklerin söz konusu şiddet içeren oyun ve filmlerle yarışabilecek düzeyde hazırlanması bir alternatif oluşturabilir.

- Öğretmenin de rehberliğinde öğrencilerin boş zamanlarını değerlendirebileceği farklı etkinlikler için (gençlik merkezleri, kültürel ve sportif faaliyetler vb.) daha fazla imkânlar sağlanabilir.

- Öğretmen ve öğrencileri kontrollü bir şekilde sosyal ağda buluşturabilecek projeler geliştirilebilir.

- Okul aile birlikleri bu konuda alt komisyonlar oluşturarak şiddet içerikli dizi ve filmlere karşı kampanyalar yürütebilir ve velileri bilgilendirme çalışmaları yapabilir.

- Ailelerin farkındalığı ve örgütlenmesi artırılarak bu konuda gerekli mercilere şikâyet ya da uyarı bilinci geliştirilebilir.

- Gelecek araştırmalarda suç oranının yüksek olduğu tespit edilen bir okulla birlikte bu oranın düşük seviyede olduğu benzer sosyoekonomik ve eğitimsel düzeye sahip bir başka okul kıyaslanarak dizi filmlerin ve bilgisayar oyunlarının etkileri nitel olarak derinlemesine analiz edilip kıyaslanabilir.

\section{Kaynakça}

Akbaba Altun, S., \& Erdur Baker, Ö. (2010). School violence: a qualitative case study. Procedia Social and Behavioral Sciences, 2, 3165-3169.

Alpanık, F. (2011). Resmi İlköğretim Okullarında Okul İçi Şiddet Algısı İle Motivasyon Arasındaki İlişkinin İncelenmesi. Yayımlanmamış Yüksek Lisans Tezi, Marmara Üniversitesi, İstanbul.

Ammermueller, A. (2012). Violence In European Schools: A Widespread Phenomenon That Matters For Educational Production. Labour Economics, 19, 908-922. 
Avcı, A. (2010). Aile Yapı ve Atmosferinin Okul Şiddetine Etkisi. Değerler Ĕ̆itimi Dergisi 8 (19) 7-52.

Beycioğlu, K., Kesik, F., \& Kondakçı, Y. (2014). Eğitim Yönetiminde Güncel Tartışmalar. S. Turan (Ed.), Eğitim Yönetimi Teori, Araştırma ve Uygulama içinde (s. 387-417). Ankara: Pegem Akademi.

Browne, K. D., Hamilton-Giachritsis, C. (2005). The Influence Of Violent Media On Children And Adolescents: A Public-Health Approach. Lancet 365, 702-10.

Cantor, J. (2000). Media Violence. Journal of Adolescent Health 27, 30-34.

Carnagey, N. L., Anderson, C. A., Bushman, B. J. (2007). The Effect Of Video Game Violence On Physiological Desensitization To Real-Life Violence. Journal of Experimental Social Psychology 43, 489-496.

Creswell, J. W. (2013). Araştırma Deseni. (Çev. Selçuk Beşir Demir (Ed.)). İstanbul: Eğiten Kitap

Çubukçu, Z., \& Dönmez, A. (2012). İlköğretim Okul Yöneticilerinin Şiddet Türlerine Yönelik Görüşleri Ve Şiddetle Başa Çıkma Yöntemleri. Kuram ve Uygulamada Eğitim Yönetimi [Educational Administration: Theory and Practice], 18(1), 37-64.

Demirok, M., Ozdamli, F., Hursen, C., Ozcınar, Z., Kutguner, M., Uzunboylu, H. (2012). The Relationship of Computer Games and Reported Anger in Young People. Australian Journal of Guidance and Counselling 22 (1), 33-43.

Dill, K. E., Dill, J. C. (1998). Video Game Violence: A Review of the Empirical Literature. Aggression and Violent Behavior, 3, (4) 407-428.

Erol, F. (2009). Okulda Güvenlik Sorununa Yol Açan Etkenlerin Belirlenmesi. Ankara: EARGED.

Ferguson, C. J. (2011). Video Games and Youth Violence: A Prospective Analysis in Adolescents. J Youth Adolescence 40, 377-391.

Ferguson, C. J., Rueda, S. M., Cruz, A. M., Ferguson, D. E., Fritz, S., Smith, S. M. (2008). Violent Video Games and Aggression: Causal Relationship or Byproduct of Family Violence and Intrinsic Violence Motivation? Criminal Justice and Behavior 35, 311-332.

Funk, J. B., Baldacci, H. B., Pasold, T., Baumgardner, J. (2004). Violence Exposure in Real-Llife, Video Games, Television, Movies, and the Internet: Is There Desensitization? Journal of Adolescence 2, 23-39.

Gentile, D. A., Lynch, P. J., Linder, J. R., Walsh, D. A. (2004). The Effects Of Violent Video Game Habits On Adolescent Hostility, Aggressive Behaviors, And School Performance. Journal of Adolescence 27, 5-22.

Griffiths, M. (1999). Violent Video Games and Aggression: A Review of the Literature. Aggression and Violent Behavior 4, (2), 203-212. 
Huesmann, L. R. (2007). The Impact of Electronic Media Violence: Scientific Theory and Research. Journal of Adolescent Health 41, 6-13.

Kapıcıoğlu, İ. (2008). Üniversite Öğrencilerinin Şiddet Algısı. Yayımlanmamış Yüksek Lisans Tezi, Selçuk Üniversitesi, Konya.

Kıran, Ö. (2011). Şiddet İçeren Bilgisayar Oyunlarının Ortaöğretim Gençliği Üzerindeki Etkileri (Samsun Örneği). Yayımlanmamış Yüksek Lisans Tezi, Ondokuz Mayıs Üniversitesi, Samsun.

Kızmaz, Z. (2006a). Şiddetin Sosyo-Kültürel Kaynakları Üzerine Sosyolojik Bir Yaklaşım. Fırat Üniversitesi Sosyal Bilimler Dergisi 16(2), 247-267.

Kızmaz, Z. (2006b). Okullarda Şiddet Davranışının Kaynakları Üzerinde Kuramsal Bir Yaklaşım. C.Ü. Sosyal Bilimler Dergisi 30 (1), 47-70.

Krug, E. G., Dahlberg, L. L., Mercy, J. A., \& Anthony B. Zwi, R. L. (2002). World Report On Violence And Health. World Health Organization (WHO), Geneva.

MEB. (2008a). Öğrencilerin Şiddet Algısı. Ankara: EARGED

MEB. (2008b). Öğretmenlerin Şiddet Konusundaki Bilgileri, Gözlemleri, Değerlendirmeleri ve Çz̈züm Önerileri. Ankara: EARGED

Pehlivan, M. (2008). İstanbul İli Kadıköy İlçesi Liselerindeki Okul İçi Şiddet Algısı ve Şiddete Karşı Alınan Önlemler İlişkisi. Yayımlanmamış Yüksek Lisans Tezi, Yıldız Teknik Üniversitesi, İstanbul.

Sağlam, H. (2011). Bilgisayar Oyunlarının Ergen Öğrencilerin Sosyalleşme Süreci Ve Şiddet Ĕ̆ilimleri Üzerindeki Etkileri. Yayımlanmamış Yüksek Lisans Tezi, Sakarya Üniversitesi.

Slavin, R. E. (2013). Eğitim Psikolojisi Kuram ve Uygulama (10. b.). (Çev. Galip

Yüksel (Ed.)) Ankara: Nobel.

Şener, G., Boydak Özan, M. (2013). İlköğretim Kurumlarında Yer Alan Öğretmen ve Öğrencilerin Şiddet Algıları. Sakarya University Journal of Education, 3 (1), 7-20.

Şişman, M. (2011). Türk Eğitim Sistemi ve Okul Yönetimi. Ankara: Pegem Akademi

Tanrı̈ğen, A. (Ed.). (2009). Bilimsel Araştırma Yöntemleri. Ankara: Anı Yayıncilik.

Tezcan, M. (2009). Eğitimde Şiddet Olgusunun Sosyolojik Kaynakları. 6. Ulusal Sosyoloji Kongresi Bildiri Kitabı 789-801.

TÜíK. (2013a). 06-15 Yaş Grubu Çocuklarda Bilişim Teknolojileri Kullanımı Ve Medya, 2013.

TÜiK. (2013b). Hanehalkı Bilişim Teknolojileri Kullanım Araştırması, 2013.

Yeşilyaprak, B. (Ed.). (2013). Ĕ̆gitim Psikolojisi Gelişim-Öğrenme-Öğretim (10. b.). Ankara: Pegem Akademi. 
Yıldırım, A., \& Şimşek, H. (2008). Sosyal Bilimlerde Nitel Araştırma Yöntemleri (7. b.). Ankara: Seçkin Yay.

Yörük, S., Çankaya, İ.H. (2013). School Violence In Rural and Urban Centers of Turkey (Sample of Afyon Province). The Journal of Academic Social Science Studies 6 (8), 165-178. 